\title{
Impact of eutrophication on the life cycle, population dynamics and production of Ampithoe valida (Amphipoda) along an estuarine spatial gradient (Mondego estuary, Portugal)
}

\author{
M. A. Pardal ${ }^{1, *}$, J. C. Marques ${ }^{1}$, I. Metelo ${ }^{1}$, A. I. Lillebø ${ }^{1}$, M. R. Flindt ${ }^{2}$ \\ 'IMAR (Institute of Marine Research), Department of Zoology, University of Coimbra, 3004-517 Coimbra, Portugal \\ ${ }^{2}$ University of Copenhagen, Freshwater Biological Laboratory, Helsingorsgade 51, 3400 Hillerød, Denmark
}

\begin{abstract}
The life cycle, population dynamics and production of Ampithoe valida was studied from an intertidal mudflat in central Portugal, close to the northern limit of the species' distributional range in the eastern Atlantic Ocean. Sampling was carried out in eutrophicated areas, where macroalgae blooms of Enteromorpha spp. occur usually from January to early summer, and also in non-eutrophicated areas, with Zostera noltii meadows. A. valida showed a contagious distribution and the population density clearly changed during the study period along the eutrophication gradient. No migratory patterns were detected between the estuary and the sea, but migrations inside the estuary might have occurred. Females were morphologically recognisable at smaller sizes than males. Females reached sexual maturity before males, but males may live slightly longer than females. Females are iteroparous, producing 2 , perhaps 3 , broods. A 2-generation life cycle involving a short-lived ( 7 mo), fast-growing summer generation and a longer-lived $(9 \mathrm{mo})$, slower-growing generation that overwinters is hypothesised. Ovigerous females were present year-round. Eggs, depending on the season, increase differently in volume during marsupial development. No correlations were found between fecundity (number of eggs) and the size of females. Along the eutrophication gradient no differences were found regarding the biology of the species. Besides these features, differences were observed between eutrophicated and non-eutrophicated areas with regard to productivity. Growth production (P) of $A$. valida in the most eutrophicated area was $0.098 \mathrm{~g} \mathrm{~m}^{-2} 18 \mathrm{mo}^{-1}$ and $0.64 \mathrm{~g} \mathrm{~m}^{-2} 18 \mathrm{mo}^{-1}$ in the $Z$. noltii meadows. P/B and $E / \bar{B}$ ratios (where $E$ is the elimination production and $\bar{B}$ is the average population biomass) ranged from 1.42 and 3.06 in the most eutrophicated area to 5.98 and 12.41 in the $Z$. noltii beds. To a certain extent, the increase of macroalgae biomass may favour $A$. valida populations, but extensive blooms affecting the whole area of distribution of this species will determine its disappearance.
\end{abstract}

KEY WORDS: Amphipoda - Life history · Production · Dynamics · Eutrophication · Macroalgae blooms

\section{INTRODUCTION}

Most European estuaries are affected by organic pollution and nutrient discharges, which often give rise to eutrophication (Hickel et al. 1993, Yeates 1993, Dijk et al. 1994, Flindt et al. 1997, Marques et al. 1997. Rafaelli et al. 1998). Eutrophication, as a response to nutrient enrichment, commonly causes proliferation of opportunistic green macroalgae, such

•E-mail: macpinar@gemini.ci.uc.pt as Chaetomorpha, Enteromorpha and Ulva, which can cover extensive areas of estuarine intertidal zones. It has been observed that benthic eutrophication in estuaries and coastal lagoons determines a shift from rooted plant communities, dominated by slowgrowing species, like the eelgrass Zostera, towards free-floating (or partially free-floating) faster-growing macroalgae, like Enteromorpha or UIva (Hartog 1994), as well as changes in the biomass and species composition of macroalgae (Lavery et al. 1991) and fauna (Pardal 1998). 
Seasonal intertidal macroalgae blooms (mainly of Enteromorpha spp.j have been reported in the South Arm of the Mondego estuary (Portugal) for several years (Marques et al. 1993a,b, 1997, Pardal et al. 1993, Pardal 1998, Flindt et al. 1997, Lillebo et al. 1999) due to nutrient enrichment of estuarine waters (Marques et al. 1997, Pardal 1998). As a consequence, Zostera noltii beds, which represent the richest habitat with regard to productivity and biodiversity, have been drastically reduced in the South Arm of the estuary, presumably out competed by Enteromorpha (Rafaelli et al. 1991, Hodgkin \& Hamilton 1993, Pardal 1998).

The intertidal and subtidal macrobenthic communities of the Mondego estuary were monitored from 1985 to 1990. Amphipods and isopods appeared as abundant groups, most probably playing an important role in the benthic communities (Marques \& Nogueira 1991, Marques et al. 1993a,b, 1994, Martins et al. 1997, Pardal 1998). In the South Arm of the estuary, where increasing processes of eutrophication have been occurring, it is possible to observe the spatial gradient of replacement of Zostera noltii beds by green macroalgae. In this intertidal area, Ampithoe valida (Amphipoda) is one of the most abundant species

Ampithoe valida is a grazer that can be found on rocky substrata and on muddy bottoms, often in the presence of green macroalgae or macrophytes (e.g. Zostera noltii) in salinities higher than 29 psu. This is a species previously found in the Pacific and along Atlantic coasts of North America (Conlan \& Bousfield 1982). But even with this wide distribution the species has received little attention, except a study by Borowsky (1983) on the reproductive behaviour under laboratory conditions, and there are only a few studies on the impact of macroalgae blooms on grazer amphipod species population dynamics (Drake \& Arias 1995). Such knowledge may definitely contribute to a better understanding of dynamic processes related with shift in primary producers and therefore to the understanding of its theoretical framework.

\section{MATERIALS AND METHODS}

Study site and sampling. The Mondego estuary is a warm-temperate coastal system on the western coast of Portugal (Fig. 1). It consists of 2 arms, north and south, with very different hydrological characteristics. The northern arm is deeper, while the southern arm is largely silted up, especially in upstream areas, which causes most of the freshwater discharge to flow through the northern arm. Consequently, the water circulation in the southern arm is mainly dependent on tidal activity and on the usually small freshwater input of a tributary, the Pranto River, which is controlled by a sluice.

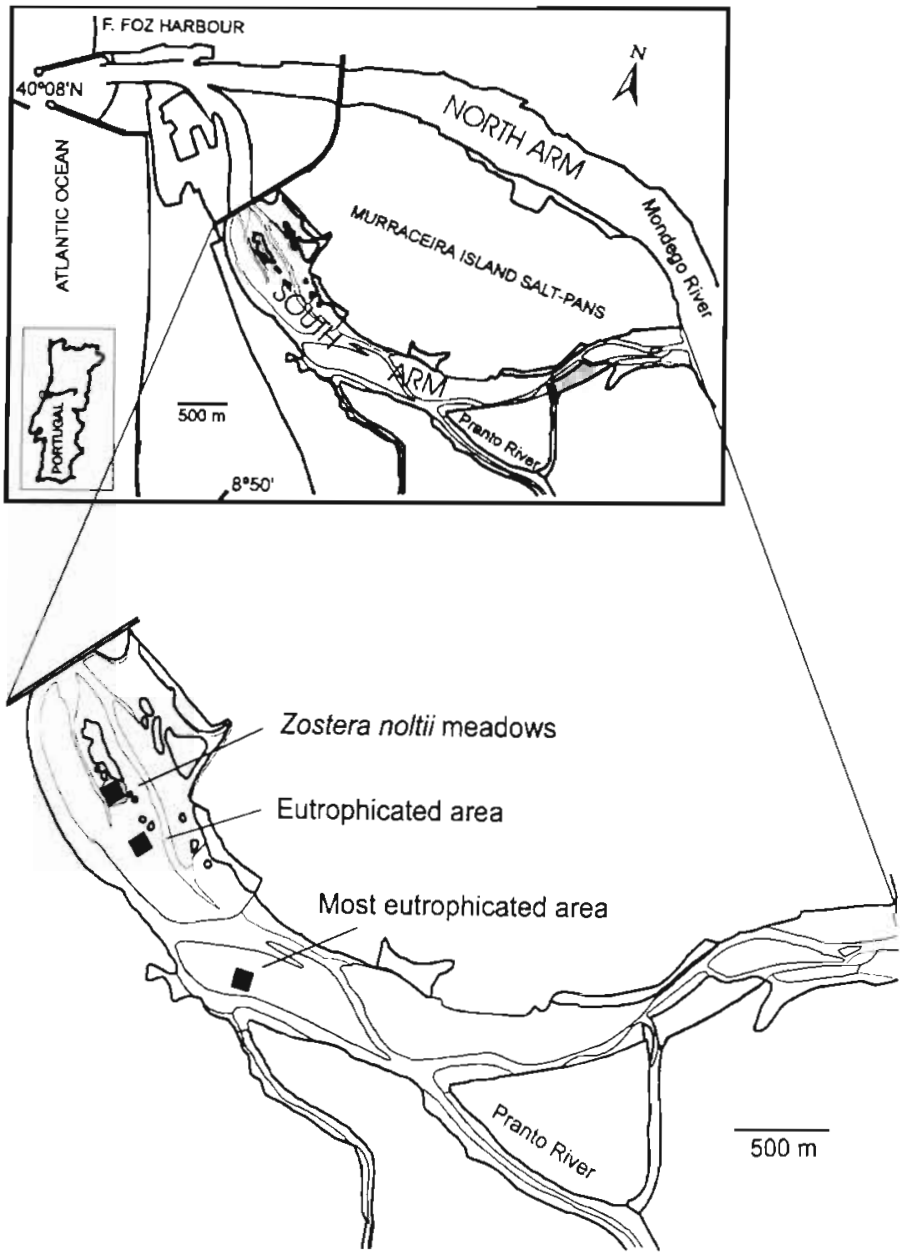

Fig. 1. Location of the sampling stations along a spatial gradient of eutrophication in the Mondego estuary, Portugal

Although, a large part of the southern arm intertidal area still remains more or less unchanged, having sand muddy bottoms covered by Spartina maritima marshes and Zostera noltii meadows, macroalgae blooms of Enteromorpha spp. have been regularly observed over the last $15 \mathrm{yr}$. This is probably a result of excessive nutrient release into the estuary, coupled with longer persistence of nutrients (nitrogen and phosphorus) in the water column (Flindt et al. 1997, Marques et al. 1997, Pardal 1998). Nevertheless, such macroalgae blooms may not occur in exceptionally rainy years (e.g. 1994) due to low salinity for long periods, as a result of the Pranto River discharge (Pardal 1998).

The population was monitored in the Mondego estuary for $18 \mathrm{mo}$, from January 1993 to June 1994. Samples of macrophytes, macroalgae, and associated amphipods were taken every 2 wk at 3 different sites during low water tide along an estuarine gradient of eutrophication in the south arm of the estuary (Fig. 1), from a non-eutrophicated zone, where a macrophyte 
community (Zostera noltii) was present, up to a heavily eutrophicated zone, in the inner areas of the estuary, from where the macrophytes disappeared while Enteromorpha spp. blooms have been observed there over the last decade. In this area, as a pattern, Enteromorpha spp. biomass normally increases from early winter (January/February) up to July, when a algae crash usually occurs due to anoxia and most of the biomass is washed out to the Atlantic.

Each time at each site 10 cores (with a $143 \mathrm{~cm}$ section) were taken to a depth of $15 \mathrm{~cm}$. Each core was placed in a separate plastic bag and sieved within an hour of sampling by washing it in estuarine water through a $500 \mu \mathrm{m}$ mesh sieve. Given the size of newly hatched juveniles, this mesh should retain all individuals. The residue (sediment, macrophytes or algae and amphipods) was placed into plastic bottles and preserved with $4 \%$ formalin in estuarine water.

Laboratory procedures. Amphipods were identified, counted, measured and sexed. Due to the difficulties in accurately measuring total body length $\left(T_{\mathrm{L}}\right)$ in such small organisms that are typically comma-shaped, an alternative and more accurate length was measured: the cephalic length $\left(C_{\mathrm{L}}\right)$ (measured between the extremity of the rostrum and the base of the head). We measured 261 individuals (males females and juveniles) for both lengths, and an equation for $C_{L}-T_{L}$ conversion was determined $\left(T_{L}=-0.1355+9.4233^{C_{L}}\right.$, $\mathrm{n}=262, \mathrm{r}=0.965)$. Length-weight relationships were determined for production estimates. Since length ashfree dry weight (AFDW) relationships did not show significant seasonal differences based on analysis of variance ( $\mathrm{p} \leq 0.05$ ), a data set obtained throughout the study was used to provide a single regression equation $\left(W[\right.$ weight $\left.]=0.00085 \times C_{L}^{3.631}, n=95, I=0.983\right)$. Individuals were dried at $60^{\circ} \mathrm{C}$ for $72 \mathrm{~h}$ and weighed to the nearest $0.01 \mathrm{mg}$. Small individuals were pooled to obtain measurable values. AFDW was assessed after combustion of samples for $8 \mathrm{~h}$ at $450^{\circ} \mathrm{C}$. The same procedure was used to quantify the macroalgae and Zostera noltii biomasses.

The determination of sex was based on the presence or absence of oostegites and/or broods (females), and of genital papillae (males). Animals without these features were considered to be juveniles. When broods were present, eggs were counted (to estimate the fecundity). measured and examined to determined the development stage. Taking into consideration several similar criteria (Steele \& Steele 1969, Goedmakers 1981, Skadsheim 1982, Marques \& Nogueira 1991, Marques et al. 1994) 5 stages were considered: (1) newly laid, eggs grouped and resembling a gelatinous mass; (2) eggs well separated, internally homogeneous; (3) embryo commashape, pereopods starting to be visible; (4) constriction of the comma clearly visible, appendages segmented and looking slender, eyes visible, cephalotorax orange-red; (5) hatched and free juveniles, which may stay for some days in the brood pouch. Since eggs become oval in shape during development, an average of their length and width was taken as measurement of their size.

Statistical analysis. An index, $I=S^{2} X / \bar{X}$ where $S^{2}$ is the variance of abundances and $\bar{X}$ is the mean abundance; Elliot 1977) was used to analyse the population spatial dispersion. Stepwise, least squares multiple regression models for Ampithoe valida were developed to examine the relationship between the density and biomass of $A$. valida and the biomass of macroalgae, salinity and water temperature. All variables except temperature and salinity were submitted to a $\ln (x+1)$ transformation prior to analysis in order to minimise heteroscedasticity. Only variables with partial effects significant at the $p<0.01$ level were retained in the regression model.

Growth. Growth rates were estimated like in previous papers of Marques \& Nogueira (1991), Marques et al. (1994), Pardal (1998), and Lillebø et al. (1999) by tracking recognisable cohorts with size frequency distributions from successive sample dates.

Growth rates are not constant throughout the year. Thus to express field growth rates, we used a model that takes into consideration seasonal changes (Gaschütz et al. 1980), expressed as:

$$
L_{t}=L_{\infty}\left[1-\mathrm{e}^{-k D(t-t)+C(k D / 2 \pi) \sin 2 \pi(t-t,)}\right] 1 / D
$$

where $L_{t}$ length of the organism at a given moment $t_{i}$ $L_{\infty}$ : maximum possible length of the organism; $t_{0}$ : instant when the organism would have a length $=0$; $t_{\mathrm{s}}$ : time interval between start of growth (when $t=0$ ) and the first growth oscillation; growth is expressed by a sine curve with a period of 1 yr (the fact that the sine function has a period of 1 yr addresses normal seasonal oscillation of growth rates with temperature. Animals under study may live less [or more] than $1 y r$, but their growth rate oscillation will be expressed by the sine curve function. The model of course is calibrated with real data from field observations); $k$ : intrinsic growth rate; $C$ : constant, whose values can change from 0 to 1 ; and $D$ : parameter that expresses metabolic deviations from the Von Bertalanffy $2 / 3$ rule.

Production. Production was estimated like in previous papers of Marques \& Nogueira (1991), Márques et al. (1994), Pardal (1998), and Lillebø et al. (1999), and was based upon cohort recognition. Growth increments or net production $(P)$ and elimination production (E) were estimated with a method derived from Allen (1971), as described in Dauvin (1986).

Total values of $P$ and $E$ for the population are expressed as:

$$
\mathrm{P}=\sum_{n=1}^{N} P_{c n}
$$




$$
\mathrm{E}=\sum_{n=1}^{N} E_{c n}
$$

$P_{c n}$ and $E_{c n}$ are the growth and elimination of cohort $n$. $\mathrm{P} / \bar{B}$ and $\mathrm{E} / \bar{B}$ ratios were determined. $\bar{B}$ (average population biomass) is expressed as:

$$
\bar{B}=(1 / T) \sum_{n=1}^{N}\left(\bar{B}_{n} t\right)
$$

where $T$ : period of study; $N$ : number of successive cohorts in the period $T_{;} B_{n}$ : average biomass of cohort $n_{i} t$ : duration of cohort $n$.

\section{RESULTS}

\section{Macrophyte and macroalgae biomasses}

As expected, Zostera noltii biomass exhibited a clear seasonal variation. During autumn and winter total biomass depended essentially on the rhizomes, while during spring and summer total biomass increased due to the growth of leaves (Fig. 2A).

The specific composition of macroalgae biomass changed very much along the eutrophication gradient. Red macroalgae, essentially Gracilaria sp., were relatively abundant at the Zostera noltii meadows, decreasing along the eutrophication gradient, while green macroalgae showed exactly the opposite pattern (Fig. 2).

In the intermediate eutrophicated area small amounts of green macroalgae were present in both spring seasons, but the biomasses estimated could not be considered a typical bloom.

In the most eutrophicated area Enteromorpha sp. exhibited a typical spring bloom in 1993, with biomass reaching $413 \mathrm{~g} \mathrm{~m}^{-2}$ (AFDW) in April. In early summer an algae crash occurred, causing a severe impact on the macrofauna in the area attained by the phenomenon (Figs. 2 \& 3). In 1994 no macroalgae bloom occurred because it was a very rainy year in the region which increased freshwater discharges (by the sluice of Pranto River), keeping salinity low. Such conditions inhibited Enteromorpha growth, since salinity was below $10 \%$ for several months.

\section{Spatial distribution and abundance}

Ampithoe valida showed an aggregated spatial distribution in the 3 study areas along the eutrophication gradient. Estimated values of $I$ were always higher than 1 (Elliot 1977). Population density changed throughout the period of study but the pattern of variation was not the same at the 3 sampling stations (Fig. 3). In the most eutrophicated area density was
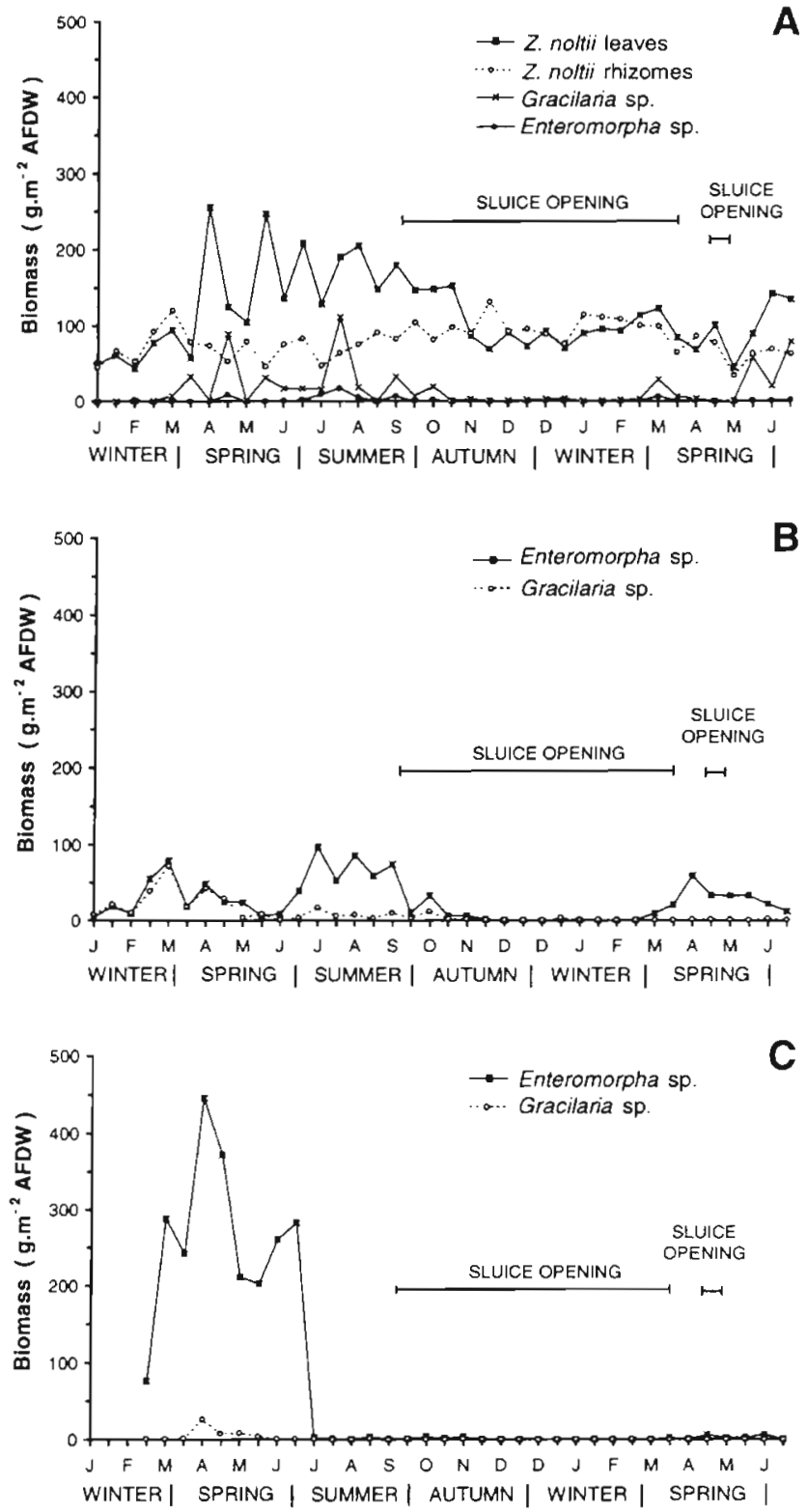

Fig. 2. Seasonal changes in plant biomass along the eutrophication gradient. (A) Zostera noltii meadows; (B) intermediate eutrophicated area; (C) most euirophicated area

consistently higher during the algae bloom, with a peak in April (2026 ind $\mathrm{m}^{-2}$ ). After the algae crash density declined sharply and remained low, or organisms even disappeared throughout the study (Fig. 3A). In the intermediate eutrophicated area the variation in density was correlated with the variation in macroalgae biomass ( $\mathrm{r}=0.87, \mathrm{n}=26$ ), but density never reached abundances as high as in the previous case (maximum peak, 154 ind. $\mathrm{m}^{-2}$ ) (Fig. 3B). With abundances so low, most of the statistical analyses that we performed in the present paper were not possible in this area. At the Zostera noltii meadows the population 

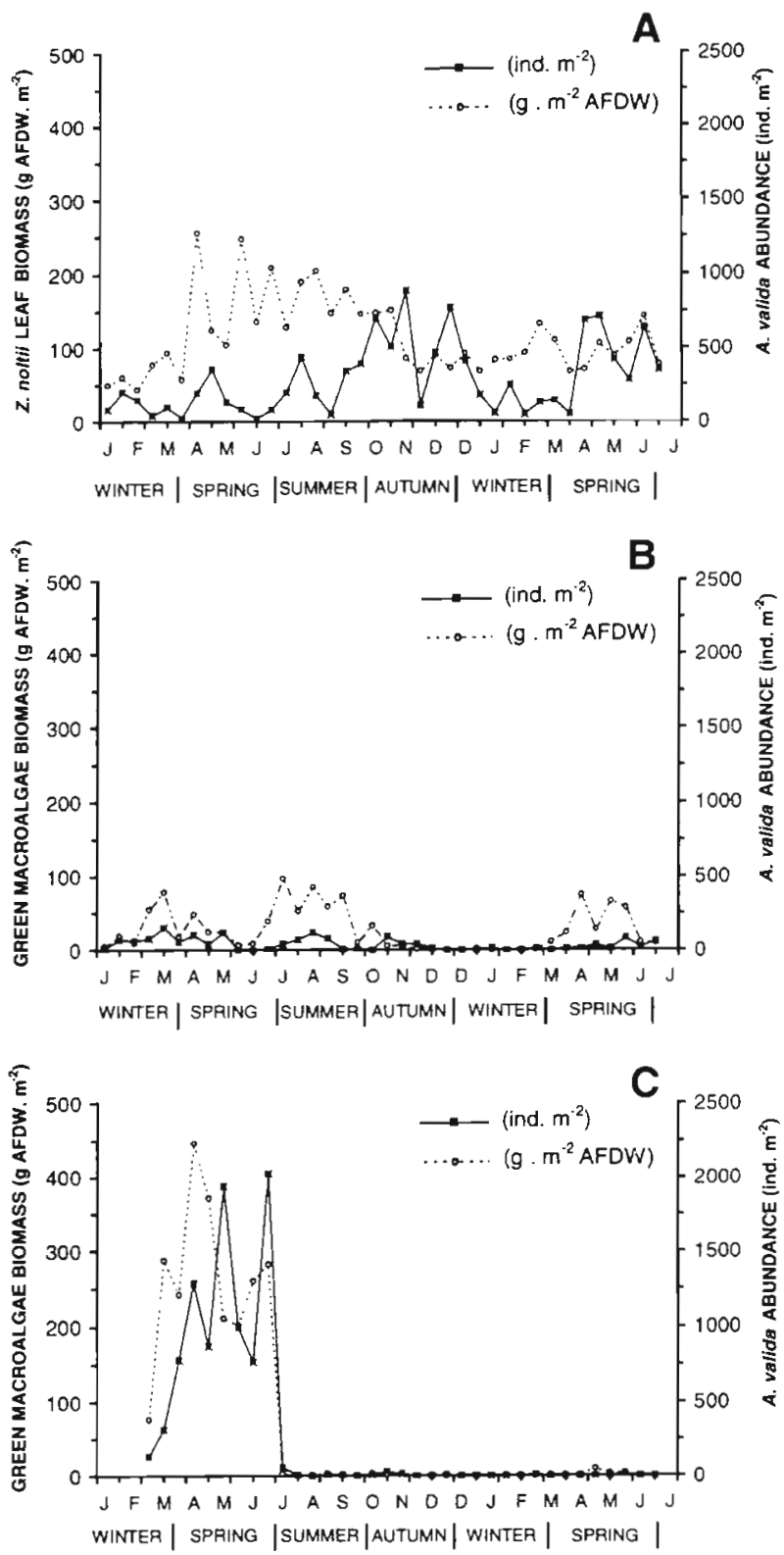

Fig. 3. Abundance of Ampithoe valida along the eutrophication gradient. (A) Most eutrophicated area; (B) eutrophicated area $_{i}$ (C) Zostera noltii meadows

density increased during summer and fall of 1993, reaching a maximum in November (887 ind $\mathrm{m}^{-2}$ ), and also during spring of 1994 (maximum peak, 710 ind. $\mathrm{m}^{-2}$ ) (Fig. 3C).

Stepwise multiple regression analysis indicated that abundance (A) and biomass (B) of Ampithoe valida in the most eutrophicated area was positively correlated with Enteromorpha sp. biomass (ENT) and Gracilaria sp. biomass (Grace):

$$
\ln (1+\mathrm{A})=0.350+1.142 \ln (1+\mathrm{ENT})
$$

$\ln (1+B)=-0.030+0.030 \ln (1+E N T)+0.096 \ln (1+$ Grace $)$
Nevertheless, in the Zostera noltii meadows no significant correlation was observed between these population parameters and leaf biomass, salinity or temperature of the water

\section{Reproduction, sex ratio, and fecundity}

The Ampithoe valida population was sexually active throughout the year in the south arm of the Mondego estuary. However, taking into consideration the percentage of ovigerous females over the total female population (Fig. 4), sexual activity was higher from late spring to late summer. The variation of the percentage of juveniles in the population was clearly related to increases in recruitment.

Females were usually more abundant than males overall, and no significant seasonal changes of this pattern were observed (Fig. 5). However, some inversions of the values might be observed, due to the death of older females after recruitment (June and August of 1993 and April/May of 1994). Males appeared to live longer than females. Also these maxima in sex-ratio
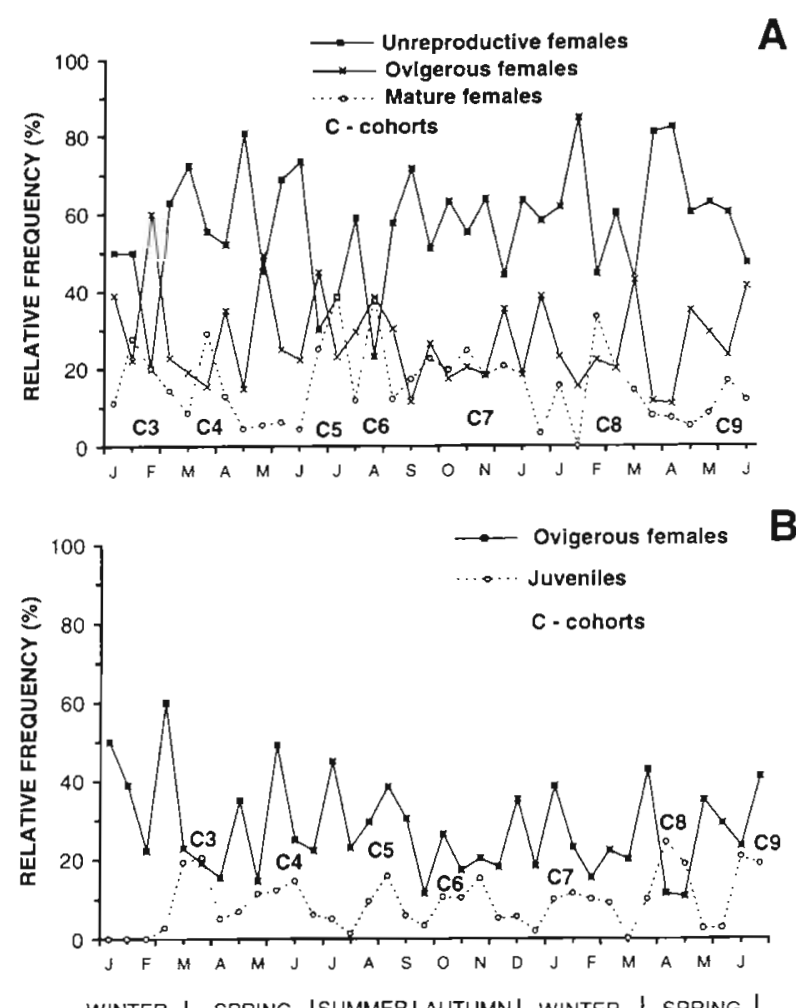

Fig. 4. Ampithoe valida. Biological features of the population (A) variation of females in different physiological stages in relation to the female population; $(B)$ variation of ovigerous females in the total female population and of juveniles in the population 


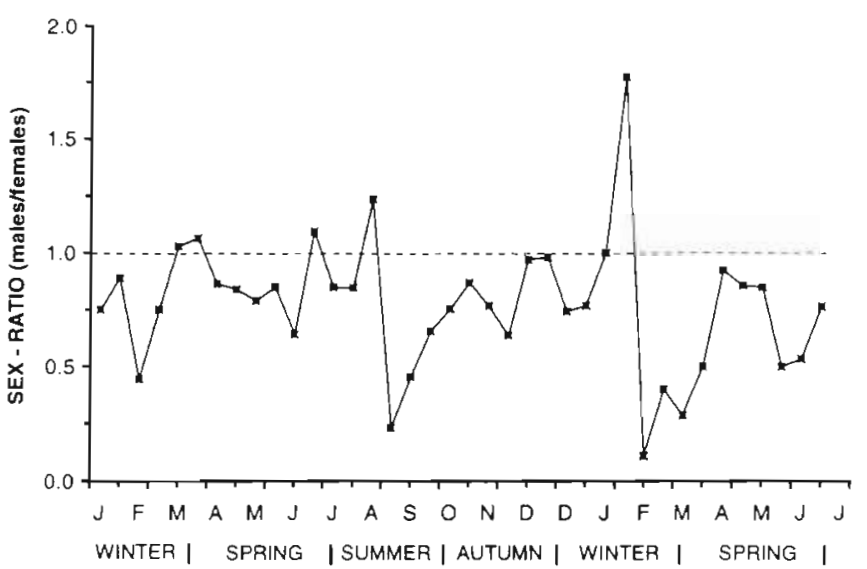

Fig. 5. Ampithoe valida. Sex ratio variation during the period of study

were normally followed by an increase in the proportions of unreproductive females.

The fecundity of females of similar size was quite variable, and no correlation between the number of developing embryos and female size was found. Measurements of eggs in different developmental stages (Table 1) showed that egg volume increase changes seasonally. For instance an increase of $361 \%$ was estimated in summer, $452 \%$ in spring and $492 \%$ in autumn. It was also possible to recognise that for the same developing stage egg volume was greater in colder periods, while the average number of eggs per female was smaller (Table 1).

The difference in time between peaks of eggs in the first stage of development (A) and the last one (E) provided us with an estimation of the duration of the embryogenic development (Fig. 6). During spring and summer the embryogenic development was faster (30 to $45 \mathrm{~d}$ ) than in autumn or winter (60 d).

\section{Growth and lifespan}

Size frequency polymodal distributions were analysed for recognisable cohorts (Fig. 7), allowing the identification of significant differences in the popula-

Table 1. Ampithoe valida. Mean number (N) and volume (Vol, $\mathrm{mm}^{3}$ ) of eggs per female at development stages $\mathrm{AB}, \mathrm{C}, \mathrm{D}$ and $E$, in the Mondego estuary

\begin{tabular}{|c|c|c|c|c|c|c|c|c|}
\hline \multirow{2}{*}{$\begin{array}{l}\text { Season } \\
\text { (1993) }\end{array}$} & \multicolumn{2}{|r|}{$A B$} & \multicolumn{2}{|r|}{ C } & \multicolumn{2}{|r|}{ D } & \multicolumn{2}{|r|}{$E$} \\
\hline & $N$ & Vol & $\mathrm{N}$ & Vol & $N$ & Vol & $\mathrm{N}$ & Vol \\
\hline Winter & 18 & 0.205 & 12 & 0.218 & 16 & 0.384 & - & - \\
\hline Spring & 16 & 0.151 & 24 & 0.186 & 18 & 0.214 & 9 & 0.682 \\
\hline Summer & 11 & 0.155 & -. & 0.170 & - & 0.167 & - & 0.56 \\
\hline Autumn & 6 & 0.218 & 11 & 0.232 & - & 0233 & - & 1.073 \\
\hline
\end{tabular}

tion structure on the Zostera beds and in the most eutrophicated area. Individuals reached larger dimensions at the most eutrophicated area in comparison with the other 2 areas ( $Z$. noltii meadows and intermediate eutrophicated areas). Nevertheless, in the first months the recruitment pattern was the same all along the eutrophication gradient. Following the algae crash the population disappeared from the most eutrophicated area and cohort tracking became only possible at the $Z$. noltii meadows. In January 1993, 3 cohorts were identified, and 6 new ones were recognised during the study period $\left(\chi^{2}\right.$ and $G$ not significant, $\left.p \leq 0.05\right)$. Minimum average $C_{L}$ of cohorts ranged from 0.327 (spring) to $0.397 \mathrm{~mm}$ (winter), corresponding to 2.946 and $3.606 \mathrm{~mm}$ of total length.

Growth was continuous through life (Fig. 8). Nevertheless, growth rates were higher during spring and summer and decreased during winter. Lower growth rates during winter were probably a function of lower temperatures and lower biomasses of macroalgae (food resources) in the estuary.

Growth data from cohort C6 were used to calibrate a growth model proposed by Gashütz et al. (1980) (Fig. 9). The model parameters were estimated as follows: $L_{\infty}$, which was fixed at a value of $1.6 \mathrm{~mm} C_{\mathrm{L}}$, slightly larger than the maximum value we observed; $k=1.401 ; T_{0}=-0.116 ; t_{s}=0.625 ; C=0.175 ; D$, since metabolic rates are not known, it was assumed that there were no deviations from the Von Bertalanffy's $2 / 3$ rule, and therefore $D$ was fixed at 1 .

Growth data fitted the model very well ( $\mathrm{r}=0.994)$. Based on the model it is clear that growth rates decreased during cold months. During the rest of the year growth rates were higher.

Lifespans were estimated at $191 \pm 30$ to $238 \pm 15 \mathrm{~d}$ for summer and spring cohorts and at $242 \pm 30$ for the autumn cohort. Similarly, the age at which females and males matured was lower in spring and summer

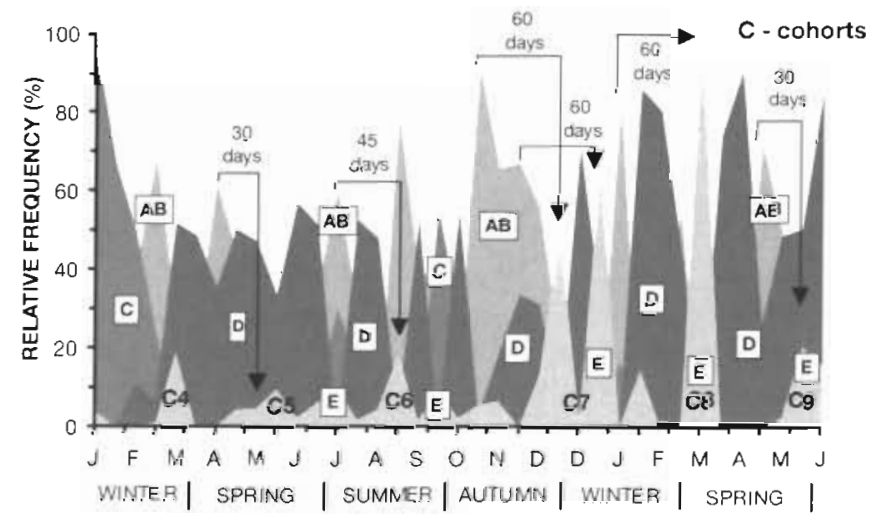

Fig. 6. Ampithoe valida. Proportion of embryos in different developmental stages. Seasonal estimation of the duration of the embryogenic development 
cohorts than in the autumn-winter cohorts (Table 2). Nevertheless, during the yearly cycle, males always reached maturity before females

\section{Production estimates}

Length-weight relationships previously established were used in production estimates in the most eutrophicated area and in the Zostera noltii meadows (Fig. 10, Table 3). Taking into account the whole period of study, results clearly showed that growth productivity $(\mathrm{P})$, elimination productivity $(\mathrm{E})$ and the relations $\mathrm{P} / \bar{B}$ and $E / \bar{B}$ were much higher in the $Z$. noltii meadows. But in the most eutrophicated area during the algae bloom $P, E$ and population density (Fig. 4) were clearly higher than in $Z$. noltii meadows (Fig. 10).

\section{DISCUSSION}

\section{Abundance}

Population density clearly changed along the eutrophication gradient as a result of the macroalgae annual dynamics, as previously observed for Microdeutopus gryllotalpa (Drake \& Arias 1995). In fact, in the most eutrophicated area, the occurrence of a macroalgae bloom in the first year prepared the conditions for the presence of large densities of Ampithoe valida. The algae crash, which acted as a catastrophic event (Marques et al. 1997), and the non-occurrence of an algae bloom in the second year had a strong effect on the population's density in the inner parts of the estuary. Consequently, since in the second spring (1994) there were no macroalgae habitats available $A$. valida individuals seemed to occur only in the Zostera noltii meadow.

During the macroalgae bloom the population density was much higher (2026 ind. $\mathrm{m}^{-2}$ by 22 June 1993) than in the Zostera noltii meadows in the same period. This may be related to habitat protection against potential predators (crabs, fishes and birds) and food resources (Greeze 1968, Duffy \& Hay 1991) since they can feed directly on the algae. Next, during the algae crash, when anoxic conditions occurred, the population suffered a sudden and drastic reduction to 56 and 0 ind. $\mathrm{m}^{-2}$ ( 6 July and 5 August). After the algae crash the population was never able to recover since no food resources were available. In contrast, in the Zostera noltii meadows the population increased in number after the algae crash. A possible movement of adult individuals inside the estuary, moving to avoid the extreme condi-
Table 2. Ampithoe valida. Annual cycle of maturation in the Mondego estuary

\begin{tabular}{|lcc|}
\hline \multirow{2}{*}{ Season } & \multicolumn{2}{c|}{ Maturation (d) } \\
& Males & Females \\
\hline Winter & 44 & 61 \\
Spring & 24 & 28 \\
Summer & 35 & 37 \\
Autumn & 41 & 57 \\
\hline
\end{tabular}

tions of anoxia, is the most probable explanation, together with new recruitments taking place in this area. During this specific period the movement of adult individuals was identified based on the observation that the older cohorts increased greatly in number of individuals with no other possible explanation available. It seems therefore that this species has a large potential for dispersion inside the estuary, avoiding as much as possible the situations of stress caused by macroalgae blooms in early summer. It seems reasonable to conclude that to a certain extent the development of macroalgae biomass favours Ampithoe valida populations, but extensive blooms affecting the whole area of distribution of this species will determine its disappearance.

\section{Reproduction, growth and life cycle}

Data showed that females almost always outnumbered males, which is a common feature in amphipod populations (Hastings 1981, Dauvin 1988a,b, Marques \& Nogueira 1991, Morritt \& Stevenson 1993, Covi \& Kneib 1995, Sudo \& Azeta 1996). The values were close to 1:1 only after recruitments, as a function of the death of older females after reproduction. Moreover, young males developed secondary sexual characteristics earlier than females (Table 2).

The duration of the embryogenic development in amphipods from high latitudes is very long and can reach 6 mo (Bregazzi 1972). In contrast, in temperate coastal areas it is much faster, taking usually only a few weeks (Steele \& Steele 1973, Moore 1981, Powell $\&$ Moore 1991). In our case embryogenic development

Table 3. Ampithoe valida. Production estimates at Zostera noltii meadows and at the most eutrophicated area, taking into account the whole period of study $(18 \mathrm{mo})$

\begin{tabular}{|lllllr|}
\hline & $\begin{array}{c}\mathrm{P} \\
\left(\mathrm{g} \mathrm{m}^{-2} \mathrm{mo}^{-1}\right)\end{array}$ & $\begin{array}{c}\bar{B} \\
\left(\mathrm{~g} \mathrm{~m}^{-2}\right)\end{array}$ & $\begin{array}{l}\mathrm{P} / \bar{B} \\
\left(\mathrm{~g} \mathrm{~m}^{-2} \mathrm{mo}^{-1}\right)\end{array}$ & $\mathrm{E} / \bar{B}$ \\
\hline Z. noltii meadows & 0.64 & 0.11 & 5.98 & 1.32 & 12.41 \\
Most eutrophicated area & 0.098 & 0.069 & 1.42 & 0.211 & 3.06 \\
\hline
\end{tabular}



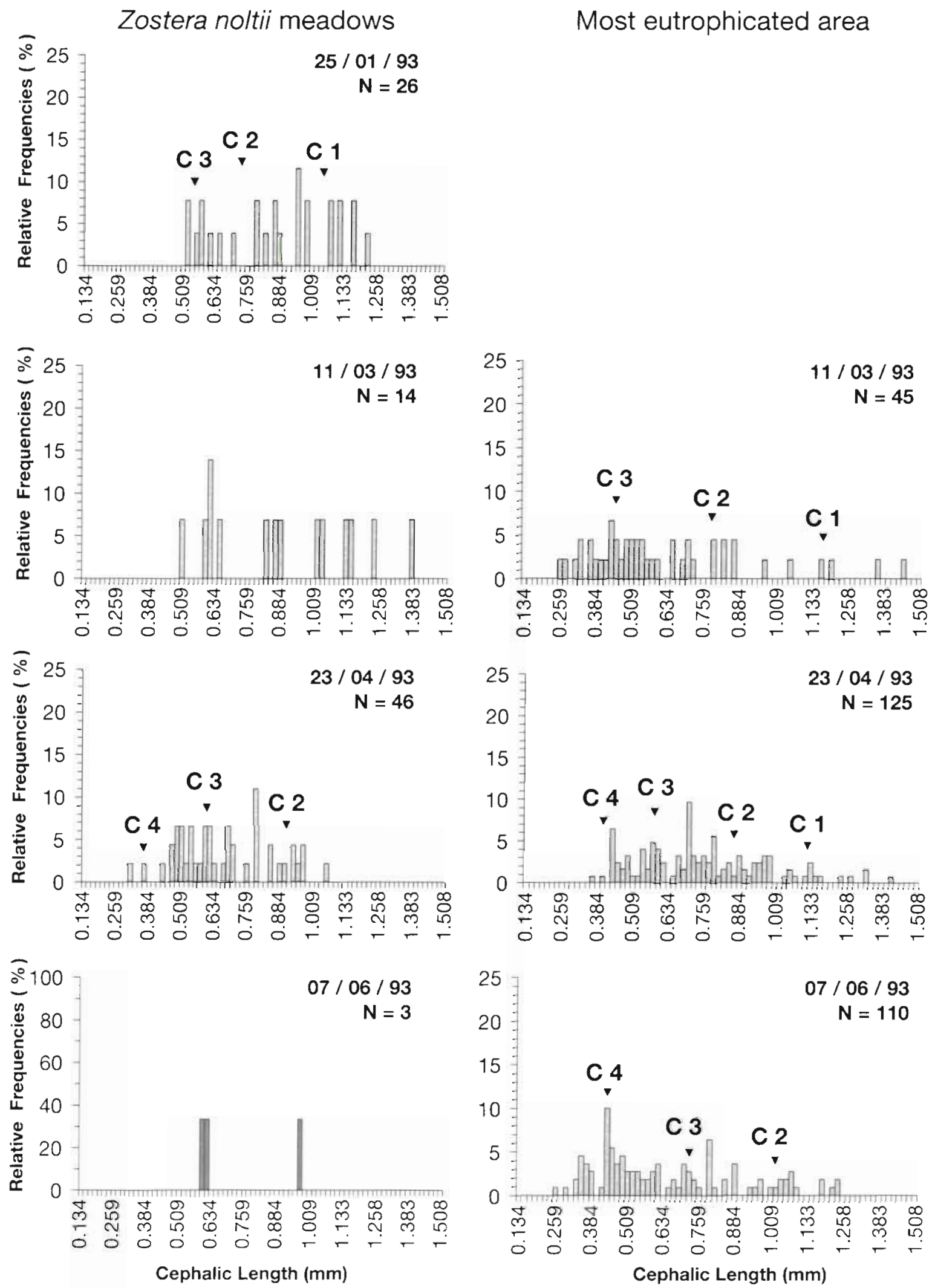

Fig. 7 Ampithoe valida. Size-frequency polymodal distribution at Zostera noltii meadows and at the most eutrophicated area. Arrowheads indicate average cephalic length of numbered cohorts; $N$ : number of individuals 

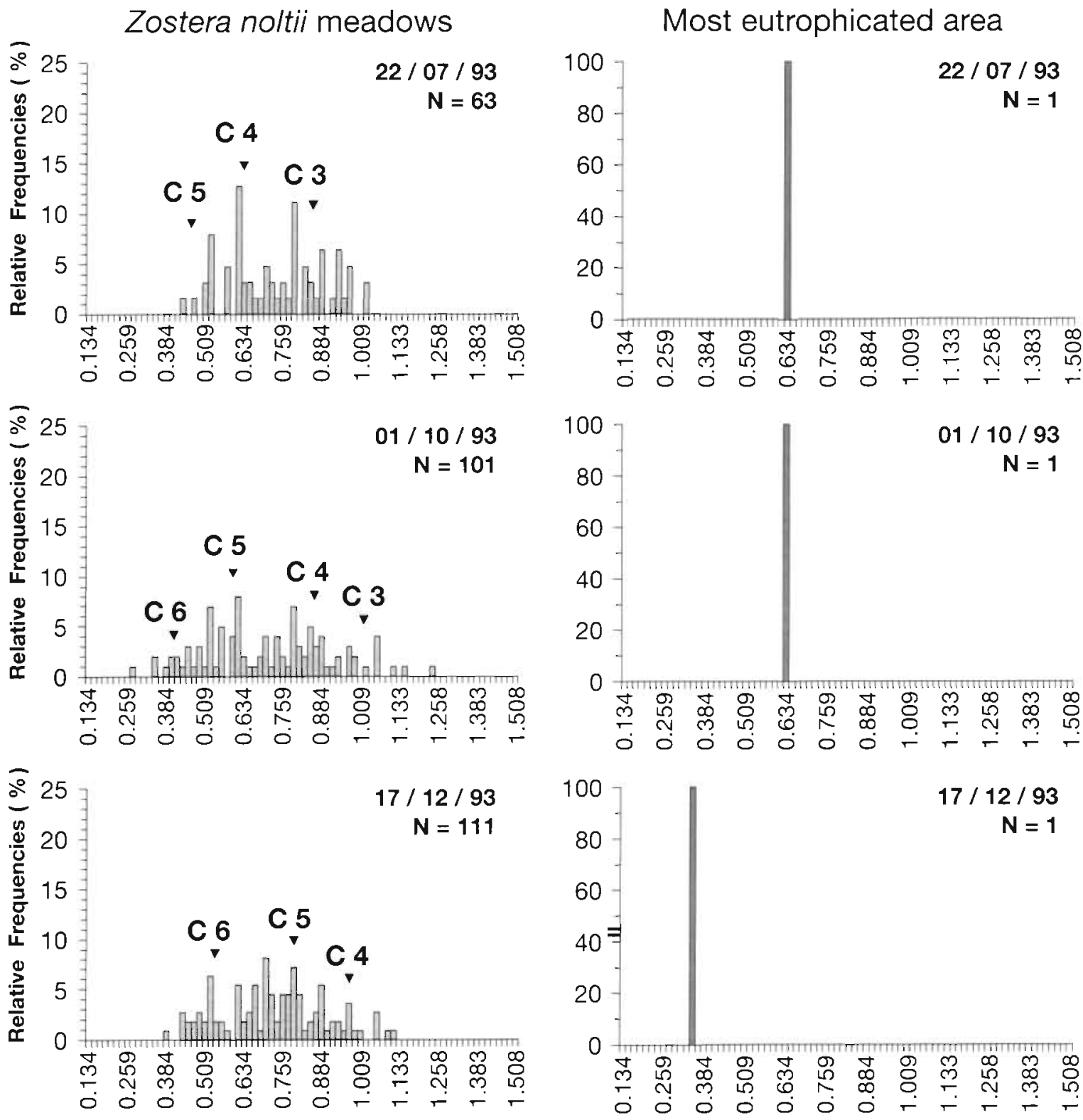

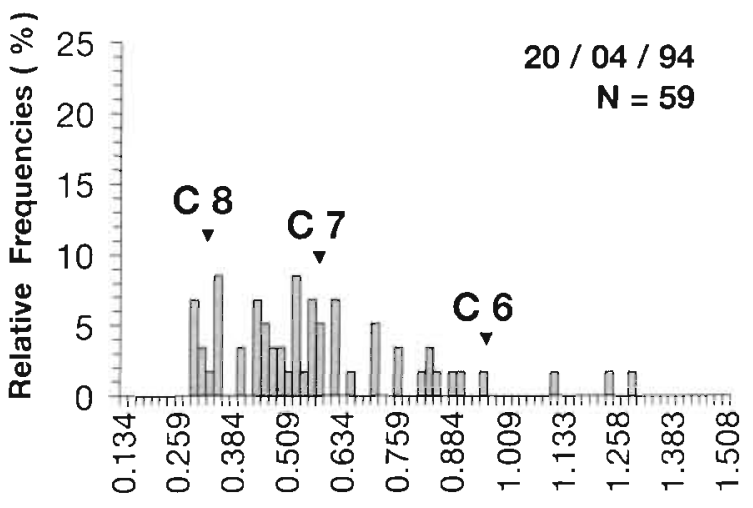

Cephalic Length $(\mathrm{mm})$

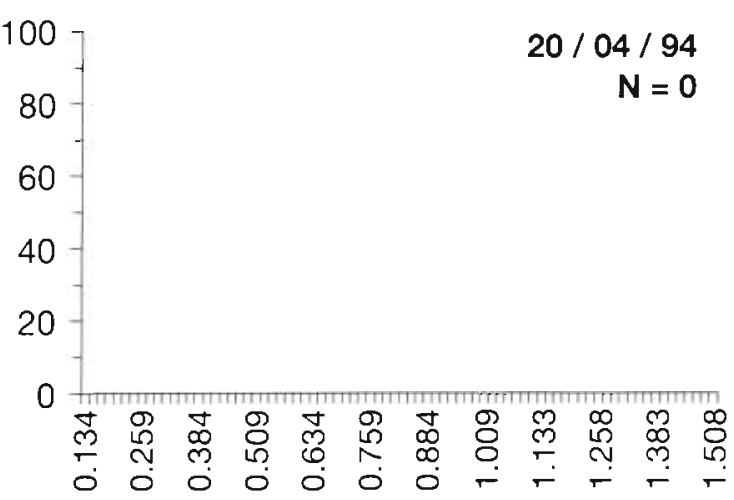

Cephalic Length $(\mathrm{mm})$

Fig. 7. (continued) 

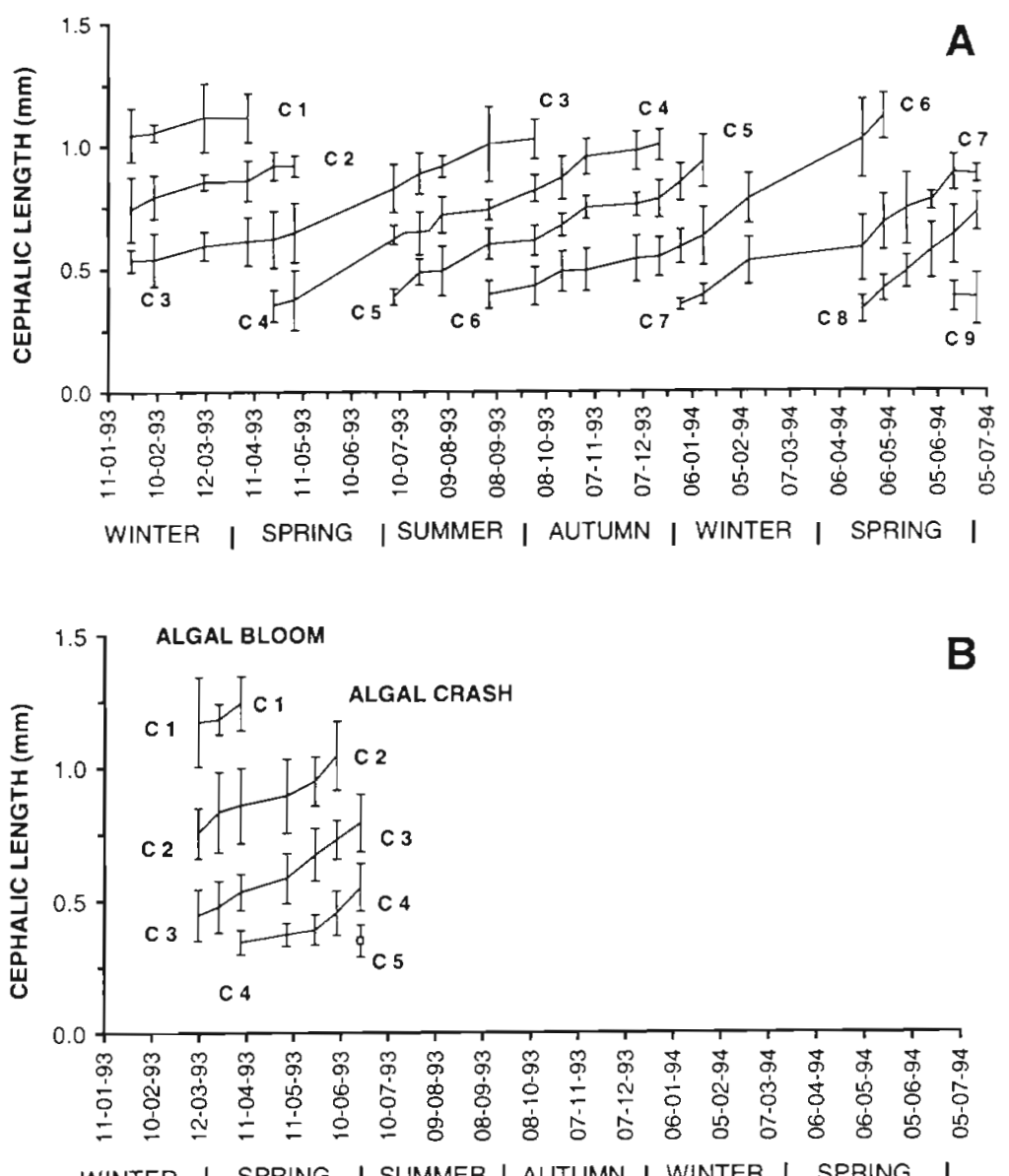

Fig. 8. Ampithoe valida. Estimated growth (field growth data) of cohorts \pm standard deviation. (A) Zostera noltii meadows; (B) most eutrophicated area Dates on the $x$-axis given as d-mo-yr

was fast but showed seasonal variations, from $30 \mathrm{~d}$ in spring up to $60 \mathrm{~d}$ in autumn and winter (Fig. 6). These values are much larger than the ones estimated by Borowsky (1983) under laboratory conditions. In such conditions Borowsky estimated 10 to $18 \mathrm{~d}$ for the female intermolt period, which corresponded to the length of time necessary for the amphipod broods to complete development and leave the marsupium. One possible explanation is based on the fact that some amphipod populations in temperate areas exhibit a fortnightly ( 14 d) reproductive rhythm (Sheader 1978, Fish \& Mills 1979, Moore 1981). So probably the Ampithoe valida population used by Borowsky (1983) (collected at Gateway National Park, USA) presented these biological features in contrast to the Mondego estuary population. During development the eggs increased almost $500 \%$ in volume in winter periods but only $361 \%$ in summer. In colder months the developing embryos (in fewer number) are present in larger volumes, which optimise chances of survivorship since they contain higher nutritive reserves. Such volume increase was higher than the one observed by Moore \& Wong (1996), although they were similar to the ones calculated by Marques \& Nogueira (1991) for Echinogammarus marinus. Moreover, in spring and summer sexual maturity was reached at smaller sizes in comparison with autumn cohorts, which agrees with previous observations on other amphipods (Moore 1981, Powell \& Moore 1991, Sudo \& Azeta 1996).

Ovigerous females of Ampithoe valida were found throughout the year in the Mondego estuary, and the population is multivoltine with a maximum of 3 generations $\mathrm{yr}^{-1}$. Continuous sexual activity during the year is a common feature in amphipods (Franz 1989, Marques \& Nogueira 1991, Covi \& Kneib 1995, Drake \& Arias 1995, Moore \& Wong 1996). Unfortunately the life cycle of this species at different latitudes was not studied, but our results are consistent with the generalised notion that ecosystems with warmer temperature regimes allow earlier maturation and higher voltinism (Birklund 1977, Marques \& Nogueira 1991, Sudo \& Azeta 1996).

Summer and spring growth rates were much higher than during colder months, which was also observed for other amphipod species in temperate areas (Hastings 1981, Dauvin 1988a, b, Franz 1989, Marques \& Nogueira 1991, Uitto \& Sarvala 1991, Drake \& Arias 1995, Wilson \& Parker 1996), and our estimated growth rates were similar to other spe-

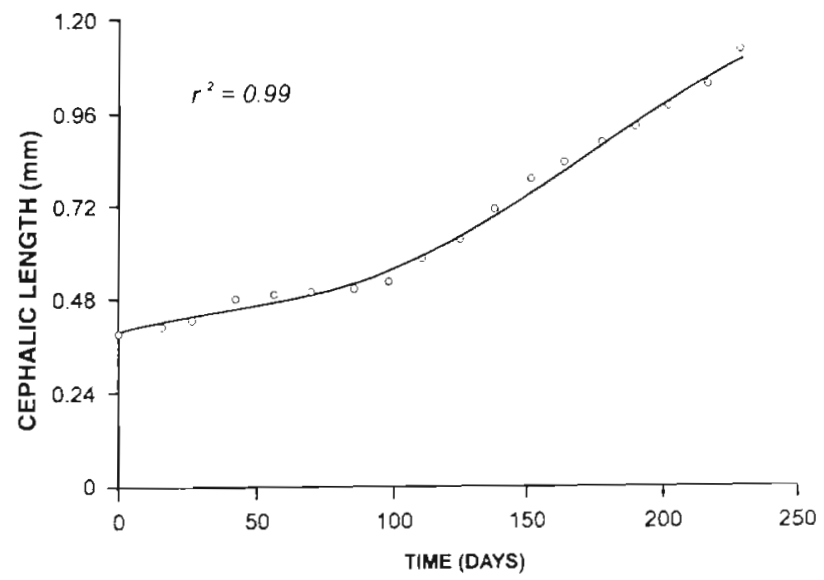

Fig. 9. Ampithoe valida growth model calibrated with fieldgrowth data (plotted points); r: correlation between predicted and observed values 

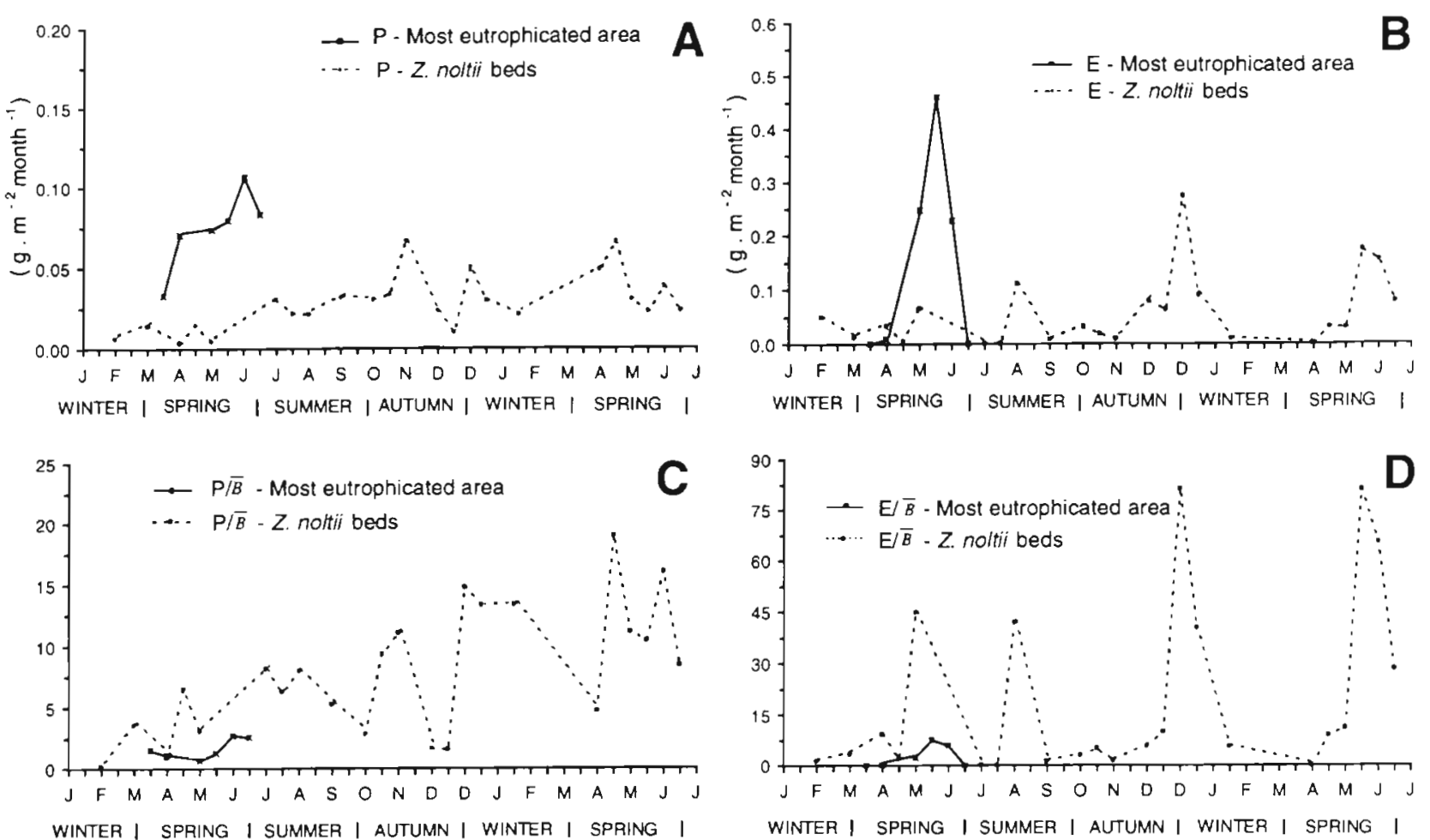

Fig. 10. Monthly variation in Ampithoe valida production estimates. (A) Net production (P); (B) elimination production (E); (C) $P / \bar{B}$ ratios; (D) $E / \bar{B}$ ratios

cies at the same latitude (Ali \& Salman 1987, Marques \& Nogueira 1991, Drake \& Arias 1995).

Like other amphipod species, Ampithoe valida is a semi-annual with short-lived spring and summer generations ( 7 to $8 \mathrm{mo}$ ) and long-lived autumn and winter generations (9 mo) (Moore 1981, Powell \& Moore 1991, Beare \& Moore 1994, Sudo \& Azeta 1996).

Ampithoe valida appeared as an $\mathrm{r}$ strategist, with iteroparous females (except summer generation), a multivoltine cycle, high individual fecundity and recruitment throughout the year. This is the most common pattern in epifaunal species (van Dolah 1980) from physically controlled communities according to the stability-time theory (Sanders 1969). In environmentally stressed systems like estuaries we should expect the evolution of opportunistic adaptive strategies to take place.

\section{Production estimates}

Taking into account the whole period of study, $P$ (growth productivity) and $\mathrm{E}$ (elimination productivity) as well as $\bar{B}$ (standing stock) showed significantly higher values in the Zostera noltii beds than in the most eutrophicated area. Nevertheless, this difference does not reflect the entire reality. In fact we must look carefully at the dynamics of the 2 areas. For a short period (during the macroalgae bloom) in the most eutrophicated area $P, E$ and $\bar{B}$ were higher than in the $Z$. noltii meadows. This means that during the macroalgae bloom the most eutrophicated area was clearly the preferential habitat for Ampithoe valida in the Mondego estuary probably due to resource availability (Fig 10).

The results clearly suggest that Ampithoe valida population dynamics and spatial distribution may change as a function of environmental changes through adaptative behavioural mechanisms. Nevertheless, it appears that macroalgae may mainly represent a good additional resource for populations with a stable habitat like Zostera noltii beds. But the macroalgae mats alone cannot sustain stable populations of $A$. valida due to their own dynamics. A conclusion would be that the total replacement of $Z$. noltii by macroalgae mats would negatively affect this kind of grazer.

As in other intertidal areas of Europe and North America, Ampithoe valida in the Mondego estuary is quite accessible to aquatic predators. High $\mathrm{P} / \bar{B}$ and $\mathrm{E} / \bar{B}$ ratios found in the Zostera noltii meadows, as well in the most eutrophicated area during the macroalgae bloom (Table 3, Fig. 10), suggest that this species may play a more important role in the trophic dynamics than one might expect from its standing stock biomass. 
As pointed out by Fredette \& Diaz (1986), our results show that in warm shallow marine habitats relatively low biomass of benthic invertebrates can result in large production estimates, because a lack of extreme cold temperatures might allow prolonged reproduction periods (Kalejta \& Hockey 1991).

As a whole, the present work reinforces the generalised notion that estuaries are highly productive systems, and reflect the important role of amphipods in the productivity of habitats colonised by them. In the Mondego estuary, although macroalgae seem to be favourable for this amphipod population, if we look at the following effects of the algae crash it is reasonable to conclude that more extensive blooms which affect the whole area of distribution of the species will, on the contrary, have a strong negative impact and could imply ist disappearance.

Acknowledgements. This paper was carried out in the scope of the WET-project (Wetland, Ecology and Technology), financed by the European Scientific TMR Program (ERB $4061 \mathrm{PL}$ 95-0832). The authors are indebted to all colleagues who assisted in field and laboratory work

\section{LITERATURE CITED}

Ali MH, Salman SD (1987) Growth and production of the amphipod Parhyale basrensis (Talitridae) in the Shatt al-Arab region. Mar Ecol Prog Ser 40:231-238

Allen KR (1971) Relation between production and biomass. J Fish Res Board Can 28:1573-1581

Beare DJ, Moore PG (1994) Observations on the biology of a rare british marine amphipod: Monoculodes gibbosus (Crustacea: Oedicerotidae). J Mar Biol Assoc UK 74:193-201

Birklund J (1977) Biomass, growth and production of the amphipod Corophium insidiosum Crawford, and preliminary notes on Corophium volutator (Pallas). Ophelia 16: $187-203$

Borowsky B (1983) Reproductive behaviour of three tubebuilding peracarid crustaceans: the amphipods Jassa falcata and Ampithoe valida and the tanaid Tanais cavolinii. Mar Biol 77:257-263

Bregazzi PK (1972) Life cycles and seasonal movements of Cheirimedon femoratus (Pfeffer) and Tryphosella kergueleni (Miers) (Crustacea: Amphipoda). Br Antarct Surv Bull 30: $1-34$

Conlan KE, Bousfield EL (1982) The amphipod superfamily Corophioidea in the North-Eastern Pacific region. Family Amphithoidae: systematics and distributional ecology. Nat Mus Can Publ Biol Oceanogr 10:41-75

Covi MP, Kneib RT (1995) Intertidal distribution, population dynamics and production of the amphipod Uhlorchestia spartinophila in a Georgía, USA, salt marsh. Mar Biol 121:447-455

Dauvin JC (1986) Dynamique de la population d'Abra prismatica (Mollusque, Bivalve) de la baie de Morlaix (Manche occidentalej. Ann Inst Océanogr Paris 62:1-12

Dauvin JC (1988a) Biologie, dyramique et production de populations de Crustacés Amphipodes de la Manche Occidentale. 1. Ampelisca tenuicornis Liljeborg. J Exp Mar Biol Ecol 118:55-84
Dauvin JC (1988b) Life cycle dynamics and productivity of Crustacea-Amphipoda from the western English Channel. 4. Ampelisca armoricana Bellan-Santini et Dauvin. J Exp Mar Biol Ecol 123:235-252

Dijk GM, Liere L, Admiraal W, Bannink BA, Cappon JJ (1994) Present state of the water quality of European rivers and implications for management. Sci Total Environ 145: $187-195$

Drake P, Arias AM (1995) Distribution and production of Microdeutopus gryllotalpa (Amphipoda: Aoridae) in a shallow coastal lagoon in the Bay of Cadiz, Spain. J Crustac Biol 15:454-465

Duffy JE, Hay ME (1991) Food and shelter as determinants of food choice by an herbivorous marine amphipod. Ecology 72:1286-1298

Elliot JM (1977) Statistical analysis of samples of benthic invertebrates. Freshw Biol Assoc 25:1-160

Fish JD, Mills A (1979) The reproductive biology of Corophium volutator and $C$. arenarium (Crustacea: Amphipoda). J Mar Biol Assoc UK 59:355-368

Flindt MR, Kamp-Nielsen L, Marques JC, Pardal MA, Bocci M, Bendoricho G, Nielsen SN, Jørgensen SE (1997) Description of the three shallow estuaries: Mondego River (Portugal), Roskilde Fjord (Denmark) and the Lagoon of Venice (Italy). Ecol Model 102:17-31

Franz DR (1989) Population density and demography of a fouling community amphipod. J Exp Mar Biol Ecol 125: $117-135$

Fredette TJ, Diaz R (1986) Secondary production of Gammarus mucronatus Say (Amphipoda: Gammaridae) in warm temperate estuarine habitats, York river, Virginia. J Crust Biol 6:729-741

Gaschütz G, Pauly D, David N (1980) A versatile basic program for fitting weight and seasonally oscillating length growth data. Pelagic, Demersal and Shellfish Cttes, 23 p $1-23$

Goedmakers A (1981) Population dynamics of three gammarid species (Crustacea, Amphipoda) in a French chalk steam. II: Standing crop. Bijdr Dierkd (Contr Zool) 51. $31-69$

Greeze II (1968) Feeding habits and food requirements of some amphipods in the Back Sea. Mar Biol 1:316-321

Hartog C (1994) Suffocation of a littoral Zostera bed by Enteromorpha radiata. Aquat Bot 47:21-28

Hastings $\mathrm{MH}$ (1981) The life cycle and productivity of an intertidal population of the amphipod Ampelisca brevicornis. Estuar Coast Shelf Sci 12:665-677

Hickel W, Mangelsdorf P. Berg J (1993) The human impact in the German Bight: eutrophication during three decades (1962-1991) Helgol Wiss Meeresunters 47:243-263

Hodgkin EP. Hamilton BH (1993) Fertilizers and eutrophication in the southwestern Australia: setting the scene. Fert Res 36:95-103

Kalejta B, Hockey PAR (1991) Distribution, abundance and productivity of benthic invertebrates at the Berg River estuary, South Africa. Estuar Coast Shelf Sci 33:175-191

Lavery PS, Lukatelich RJ, McComb A.J (1991) Changes in the biomass and species composition of macroalgae in a eutrophic estuary. Estuar Coast Shelf Sci 33:1-22

Lillebo AI, Flindt MR, Pardal MA, Marques JC (1999) The effect of macrofauna, meiotauna and microfauna on the degradation of Spartina maritima detritus from a salt marsh area. Acta Oecol 20(4):249-258

Marques JC, Nogueira A (1991) Life cycle, population dynamics and production of Echinogammarus marinus (Leach) (Amphipoda) in the Mondego estuary (Portugal). Oceanol Acta 11:213-223 
Marques JC, Rodrigues LB, Nogueira AJA (1993a) Intertidal macrobenthic communities structure in the Mondego estuary (Western Portugal): reference situation. Vie Milieu 43:177-187

Marques JC, Maranhào P, Pardal MA (1993b) Human impact assessment on the subtidal macrobenthic community structure in the Mondego estuary (Western Portugal). Estuar Coast Shelf Sci 37:403-419

Marques JC, Martins I. Teles-Ferreira C, Cruz S (1994) Population dynamics, life history and production of Cyathura carinata (Krøyer) (Isopoda: Anthuridae) in the Mondego estuary, Portugal. J Crustac Biol 14:258-272

Marques JC, Pardal MA, Nielsen SN, Jørgensen SE (1997) Analysis of the properties of energy and biodiversity along an estuarine gradient of eutrophication. Ecol Model 102:$155-167$

Martins I, Marques JC, Jorgensen SE, Nielsen SN (1997) Modelling the effects of green macroalgae blooms on the population dynamics of Cyathura carinata (Crustacea: Isopoda) in an eutrophicated estuary. Ecol Model 102:33-53

Moore PG (1981) The life histories of the amphipods Lembos websteri Bate and Corophium bonnellii Milne Edwards in Kelp holdfasts. J Exp Mar Biol Ecol 49:1-50

Moore PG, Wong YM (1996) Observations on the life history of Orchomene nanus (Kroyer) (Amphipoda: Lysianassoidea) at Millport, Scotland as deduced from baited trapping. J Exp Mar Biol Ecol 195:53-70

Morritt D, Stevenson TDI (1993) Factors influencing breeding initiation in a beachflea Orchestia gammarellus (Pallas) (Crustacea: Amphipoda). J Exp Mar Biol Ecol 165:191-208

Pardal MA (1998) Impacto da eutrofizaçāo nas comunidades macrobentónicas do Braço Sul do Mondego (Portugal). $\mathrm{PhD}$ thesis, University of Coimbra

Pardal MA, Marques JC, Bellan G (1993) Spatial distribution and seasonal variation of subtidal polychaete populations in the Mondego estuary (western Portugal). Cah Biol Mar $34: 497-512$

Powell R Moore PG (1991) The breeding cycles of females of

Editorial responsibility: Otto Kinne (Editor),

Oldendorf/Luhe, Germany seven species of amphipod (Crustacea) from the Clyde sea. J Nat Hist 25:435-479

Rafaelli D, Limia J, Hull S, Pont S (1991) Interactions between amphipod Corophium volutator and macroalgal mats on estuarine mudflats. J Mar Biol Assoc UK 71:899-908

Rafaelli D, Raven J, Poole L (1998) Ecological impact of green macroalgae blooms. Oceanogr Mar Biol 36:97-125

Sanders HL (1969) Marine benthic diversity; a comparative study. Am Nat 102:243-282

Sheader M (1978) Distribution and reproductive biology of Corophium insidiosum (Amphipoda) on the N.E coast of England. J Mar Biol Assoc UK 58:585-596

Skadsheim A (1982) The ecology of intertidal amphipods in the Oslo fjord. The life cycles of Chaetogammarus marinus and C. stoerensis. PSZN I: Mar Ecol 3:213-224

Steele DH, Steele VJ (1969) The biology of Gammarus (Crustacea, Amphipodal in the northwestern Atlantic. I: Gammarus duebeni Lillj. Can J Zool 47:235-244

Steele D. Steele VJ (1973) The biology of Gammarus (Crustacea, Amphipoda) in the northwestern Atlantic. VIII. The duration of embryonic development in five species at various temperatures. Can J Zool 51:995-999

Sudo H. Azeta $M$ (1996) Life history and production of the amphipod Byblis japonicus Dahl (Gammaridea: Ampeliscidae) in a warm temperate zone habitat, Shijiki bay, Japan. J Exp Mar Biol Ecol 198:203-222

Uitto A, Sarvala J (1991) Seasonal growth of the benthic amphipods Pontoporeia affinis and P. femorata in a baltic archipelago in relation to environmental factors. Mar Biol $11: 237-246$

van Dolah RF (1980) A comparison of reproductive patterns in epifaunal and infaunal gammaridean Amphipoda. Estuar Coast Shelf Sci 2:593-604

Yeates JS (1993) Soils and fertilizer use in southwestern Australia. Fert Res 36:123-125

Wilson WH Jr, Parker K (1996) The life history of the amphipod Corophium volutator. the effects of temperature and shorebird predation. J Exp Mar Biol Ecol 196:239-250

Submitted: May 4, 1999; Accepted: November 2, 1999

Proofs received from author(s): March 31, 2000 